PLANT PATHOLOGY

\title{
Outbreak of Rice Blast on the Coastal Region of South-Eastern India
}

\author{
Sudeepta Pattanayak and Siddhartha Das*
}

Department of Plant Pathology, MS Swaminathan School of Agriculture, Centurion University of Technology and Management, Odisha, India

*Corresponding author: siddhartha.das10@gmail.com (ORCID ID: 0000-0002-7482-2555)

Paper No. 817

Received: $14-10-2019$

Revised: 23-01-2020

Accepted: 28-02-2020

\begin{abstract}
Rice blast caused by Magnaporthe grisea is turn to be one of the most severe pathogen under change in climatic condition in coastal region of South-Eastern India. Severity of the pathogen was not overwhelming previously. An investigation was carried out in several villages of different districts of Andhra Pradesh and Odisha under the RAWEP programme of Centurion University of Technology and Management with compared to meteorological data support from IMD, Bhubaneswar, Odisha. Different meteorological factors consider under this study were maximum temperature $\left(\mathrm{T}_{\max }\right)$, minimum temperature $\left(\mathrm{T}_{\min }\right)$, relative humidity maximum $\left(\mathrm{RH}_{\text {max }}\right)$, relative humidity minimum $\left(\mathrm{RH}_{\text {min }}\right)$, rainfall $(\mathrm{RF})$. Among the three cultivated rice varieties, Pooja and Samba mahsuri (BPT-5204) are the most susceptible blast varieties (5.71\% and $4.85 \%$ ) compared to Swarna (MTU 7029) with a disease incidence level of $1.23 \%$. Outcome of this investigation also revealed that the most crucial two $\left(\mathrm{T}_{\max }\right.$ and $\left.\mathrm{RH}{ }_{\max }\right)$ factors directly involved for the emergence of the disease compared to previous year 2015-16 and 2016-17. The peak disease infestation was observed in the month of October and November with PDI of $27.33 \%$ and $26 \%$. Farmers based prolonged survey report and our observation concluded with the fact that Tricyclazole 75\% WP (trade name - BAAN/ Indofils) and 40\% EC formulation of Isoprothiolane (trade name - Fujione / Rallis India Limited) are the two sequential most effective fungicides compared to different market based available fungicides and showed best efficacy against neck, collar and leaf blasts. Weather parameters as well as complex adaptability of the pathogenic nature (showing resistant against different fungicides) turned this Ascomycota member to a severe one.

\section{Highlights}

0 The highest rice blast disease incidence was observed in October and November. For epidemiological perspective, the two most crucial factors for the disease development are Maximum temperature, Relative humidity and Rainfall which make a tridirectional pool for disease development.

(0 From the varietal study, it was seen that Pooja and Samba mashuri is the susceptible variety towards rice blast disease while Tricyclazole $75 \% \mathrm{WP}$ and Isoprothiolane $40 \% \mathrm{EC}$ is detected as two effective chemical against this disease.
\end{abstract}

Keywords: Magnaporthe grisea, severe, meteorological, disease incidence

Rice is one of the most important major food crop in South Eastern India. Asian countries are main rice producer as well as consumer of world $90 \%$ production. The main rice producing countries are India, Bangaladesh, China, Thailand, Philippines, Myanmar, Japan. Rice cultivation is the major activity and source of income for millions of households round the globe (Magar et al. 2015).
South Eastern India specifically coastal region of Andhra and Odisha's state economy is directly linked with the improvement in production and productivity of rice in the state. Though compared to last 40 years, rice growing area of both the state has stagnated around 4.5 million hectares i.e. around $10 \%$ of the total rice area of the country. Despite its economic, strategic and cultural importance, rice 


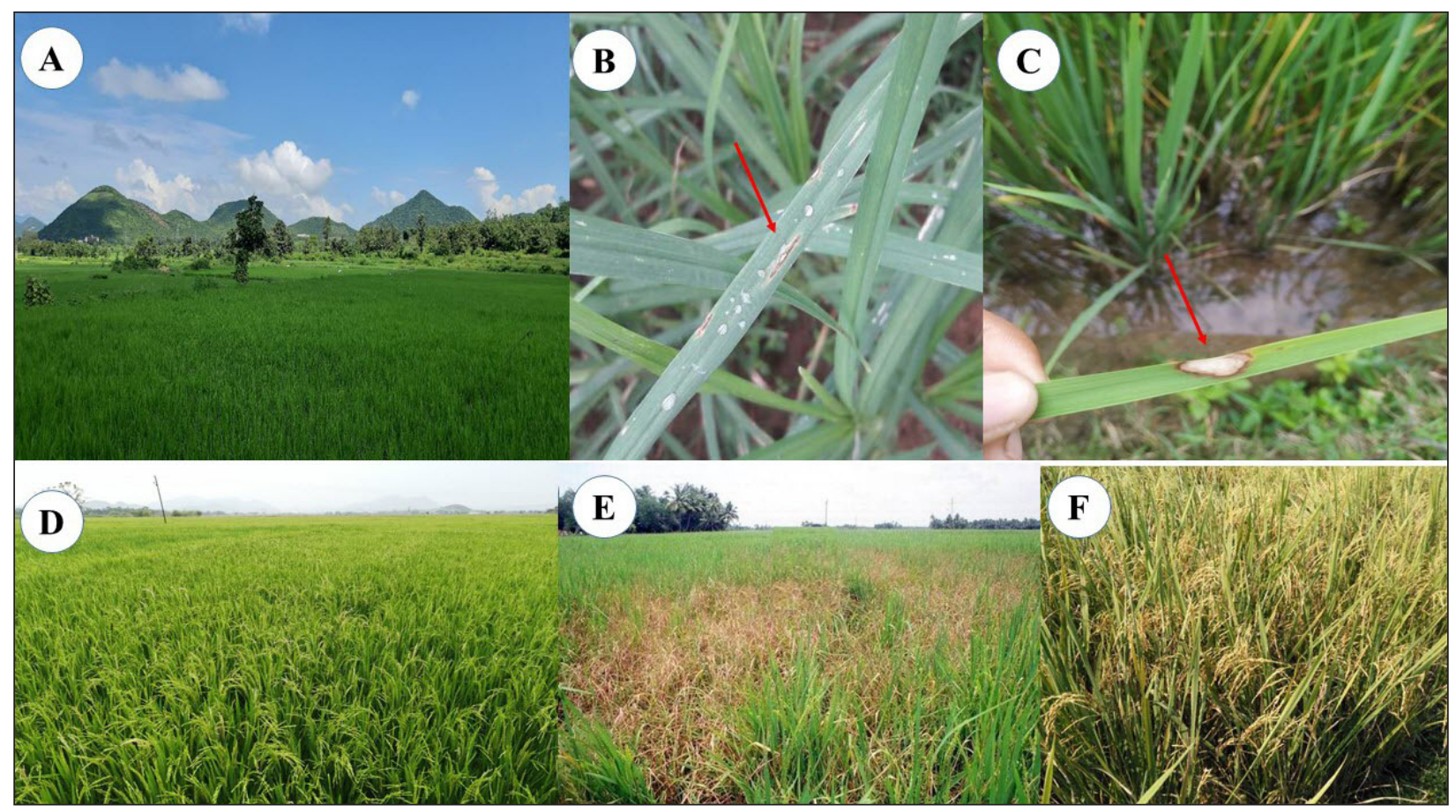

Fig. 1: (A) 20-30 days crop growth stage with no infection, (B)-(C) leaf blast symptoms, (D)-(F) Infected plants and yield

productivity in Odisha and Andhra is considerably low in the country. The total cultivated land of the state is 61.80 lakh ha and out of 29.14 lakh ha (47\%) is high land, 17.55 lakh ha (28\%) medium land and 15.11 lakh ha $(25 \%)$ low land (Das and Naik, 2015). South-Eastern region is broadly divided into two different zones i.e. Plateau region and Coastal alluvial region.

Agro-climatic condition, which prevailed in this region, are crucial and most important to act as a green corridor system for upcoming biotic and abiotic stresses on crop health. Under biotic stresses numbers of fungi, bacteria, viruses, nematodes and non-parasitic disorders are involved among which rice blast is one of the major important biotic stress, which acts as a limiting factor for rice production. Blast of rice was first introduced in this region in long past at Tanjore district of Tamil Nadu in 1918 (Pradhan et al. 2018). Rice blast pathogen is a devastating pathogen and it can cause yield loss ranging from $30-61 \%$ depending upon the stage of infection. The most severe form of blast is the Leaf and panicle blast (Zeigler and Correa. 2000). Depending on cultivar susceptibility, environmental conditions and management system, it causes yield losses up to $100 \%$ (Ou 1980). The fungus can infects all parts of the shoot (Talbot 2003; Sesma and Osbum 2004) and caused three different symptomatology
- neck, collar and leaf blast. Symptoms appears as diamond shape or eye shaped brownish lesions encircled with a yellow hallow or scattered darkish outline. Different meteorological factors played a crucial role for rice blast disease development. Sequential changes of weather variables in year after year makes the pathogen more severe and drastic in nature.

Planting of resistant cultivars, application of fungicides, and manipulation of planting times, fertilizers and irrigations are the most usual approaches for the management of this disease (Georgopoulos and Ziogas 1992; Moletti et al. 1988; Mbodi et al. 1987; Naidu and Reddy 1989). There are several methods developed for the control of blast disease (Mariappan et al. 1995) among which chemical control has been widely used in most of the countries. Prior investigation revealed that seed treatments and foliar sprays with systemic fungicides be an effective method in lessening the severity of blast disease (Manandhar 1984; Manandhar et al. 1985; Chaudhary and Sah 1998). Keeping this framework in mind, efforts have been made to find out the most crucial weather variable and their interaction for disease development. Additionally efficacy of different market based fungicides will be evaluated against this disease. 


\section{MATERIALS AND METHODS}

\section{Selection of host farmer in different agro ecological region of south eastern India}

Different host farmers were selected from different agro-ecological region by the RAWE students (Table 1). The host farmers were selected on the basis of the crop, the variety grown by them and the type of rice (Kharif rice) they are growing. The host farmers were selected from the following villages:

Table 1: Geographical Location of Different villages selected under RAWE Programme

\begin{tabular}{llll}
\hline $\begin{array}{l}\text { Sl. } \\
\text { No }\end{array}$ & Village & State & Longitude and Latitude \\
\hline 1 & Bhanur & Telengana & $17.4736^{\circ} \mathrm{N}, 78.1735^{\circ} \mathrm{E}$ \\
2 & Jajpur & Odisha & $18.7783^{\circ} \mathrm{N}, 84.0937^{\circ} \mathrm{E}$ \\
3 & Kushalapuram & Andhra & $18.2974^{\circ} \mathrm{N}, 83.8665^{\circ} \mathrm{E}$ \\
& & Pradesh & \\
4 & Ranipenta & Odisha & $18.7773^{\circ} \mathrm{N}, 84.0731^{\circ} \mathrm{E}$ \\
5 & Changudi & Andhra & $18.7637^{\circ} \mathrm{N}, 84.1152^{\circ} \mathrm{E}$ \\
& & Pradesh & \\
6 & Killipalem & Andhra & $18.2594^{\circ} \mathrm{N}, 83.9248^{\circ} \mathrm{E}$ \\
& & Pradesh & \\
7 & CH. & Andhra & $17.3843^{\circ} \mathrm{N}, 82.6904^{\circ} \mathrm{E}$ \\
& Laxmipuram & Pradesh & \\
8 & Kothapeta & Andhra & $13.4614^{\circ} \mathrm{N}, 78.3330^{\circ} \mathrm{E}$ \\
& & Pradesh & \\
9 & R. Sitapur & Odisha & $18.8034^{\circ} \mathrm{N}, 84.1369^{\circ} \mathrm{E}$ \\
10 & Bagusala & Odisha & $18.8317^{\circ} \mathrm{N}, 84.1679^{\circ} \mathrm{E}$ \\
\hline
\end{tabular}

\section{Survey and questionnaire}

The survey was done in questionnaire format (Fig. 2) by asking several questions about the crop variety they are growing, Major diseases of rice prevalent in that area, Seasonal disease incidence and the management strategy of the disease to different farmers of the village. The format of the questionnaire is given in Fig. 2.

\section{Selection of plot}

The different types of land (Upland/Lowland/ Medium land) was taken in to consideration for selection of plots. Low land plots were chosen as mainly rainfed rice was growing in the coastal region so that rain water can be harvested in the field itself for the high water required rice crop.

\section{Collection of disease sample}

The different disease samples were collected from the 10 above mentioned villages. Assessment of the disease severity was done by $0-5$ point index scale (Inglis et al. 1988):

- Scale 0- No symptom

- Scale 1- Greyish green lesion with dark green border $(>10 \%)$

- Scale 2- Spindle shaped whitish to gray centers with necrotic border (> 20-30\%)

\begin{tabular}{|c|c|c|c|c|c|c|c|}
\hline \multicolumn{8}{|c|}{ I. Crop Disease Status and Damage in the Field of Host Farmers. } \\
\hline \multicolumn{8}{|c|}{ Name of Students : } \\
\hline \multicolumn{8}{|c|}{ Name of Village : } \\
\hline \multicolumn{8}{|c|}{ Host Farmer : : } \\
\hline \multicolumn{7}{|c|}{ Name of the Crop : } & Name of Students : \\
\hline \multicolumn{7}{|c|}{ Variety : } & $\begin{array}{l}\text { Name of the Farmer : } \\
\text { Name of Crop/variety : }\end{array}$ \\
\hline \multicolumn{7}{|c|}{ Date of Sowing : } & Date of Sowing : \\
\hline \multicolumn{7}{|c|}{ Stage of the Crop } & 1. What is IDM? \\
\hline \multicolumn{7}{|l|}{ Objectives: } & 2. Do you know the components of IDM? \\
\hline \multicolumn{7}{|c|}{ - To know the status of disease incidence on the cultivated crop. } & 3. Which fungicides/bactericide is purchased by farmer? \\
\hline \multirow{4}{*}{\multicolumn{7}{|c|}{$\begin{array}{l}\text { - Students will be able to correlate the present disease incidence status with the ETL levels of the } \\
\text { disease incidence. } \\
\text { - On the basis of observation and available ETL level, the control measures to be adopted by the } \\
\text { farmer, it should be suggested by the student to the host farmer. }\end{array}$}} & 4. Who suggested them to use in the crop? \\
\hline & & & & & & & 5. Source of purchase of fungicides/bactericide? \\
\hline & & & & & & & 6. How you decide the quantity of fungicides/bactericide to be purchased? \\
\hline & & & & & & & 8. Dou you use measuring cylinder, weighing balance for correct measurement of pesticide? \\
\hline \multicolumn{7}{|c|}{ Table 2 Record of disease occurrence per meter row length for foliar disease } & \multirow{13}{*}{$\begin{array}{l}\text { 10. Whether the pesticide is applied alone or in combination? } \\
\text { 11. Whether you know the dose of fungicides/bactericide, do you calculate the dose of } \\
\text { fungicides/bactericide? } \\
\text { 12. Time and dose of application of fungicides/bactericide? } \\
\text { 13. Whether pesticides are applied as preventive or curative measures? } \\
\text { 14. Do you know the precautionary measures to avoid poisoning? } \\
\text { 15. Do you follow other methods of disease control? } \\
\text { 16. Are the RAEO, extension workers/KVK's are guiding you in disease management? }\end{array}$} \\
\hline \multirow[t]{2}{*}{ Block } & \multirow[t]{2}{*}{ Plant } & \multirow{2}{*}{$\begin{array}{c}\text { Total no. of leaves } \\
\text { present }\end{array}$} & \multicolumn{3}{|c|}{ No. of leaves affected } & \multirow{2}{*}{$\begin{array}{c}\text { Percentage of } \\
\text { disease incidence }\end{array}$} & \\
\hline & & & Top & Middle & Lower & & \\
\hline \multirow[t]{5}{*}{1} & 1 & & & & & & \\
\hline & 2 & & & & & & \\
\hline & 3 & & & & & & \\
\hline & 4 & & & & & & \\
\hline & 5 & & & & & & \\
\hline \multirow[t]{5}{*}{2} & 1 & & & & & & \\
\hline & 2 & & & & & & \\
\hline & 3 & & & & & & \\
\hline & 4 & & & & & & \\
\hline & 5 & & & & & & \\
\hline
\end{tabular}

Fig. 2: Format of questionnaire under RAWE Programme 
- Scale 3- Coalesce of spots and observation of large patches on leave (>40-60\%)

- Scale 4- Observation of Neck and node blast $(>70-80 \%)$

- Scale 5- Burning appearance of total plant, lodging and dying of the plant (>90\%)

\section{Isolation of pathogen}

The pathogen was isolated from the collected sample which was showing more disease severity. Isolation of pathogen was carried out by using Oatmeal Tomato Agar (OTA) media. For preparation of this media, $25 \mathrm{~g}$ of oatmeal was boiled with $500 \mathrm{ml}$ of water and then filtered. Agar powder $(12.5 \mathrm{~g})$ and Tomato juice $(94 \mathrm{ml})$ was mixed with the filtered solution and autoclaved at $15 \mathrm{lb}$ psi for 15min (Li-wang et al. 2019). To avoid any type of bacterial contamination, Antibiotic Chloramphenicol (100micro gram) was added with the media. After the temperature decreased to $50^{\circ} \mathrm{C}$, it was poured to Petri plate and inoculation was done in Laminar Air Flow chamber followed by placing the plates in incubator at $32 \pm 2{ }^{\circ} \mathrm{C}$ for 3 to 4 days.

\section{Microscopy}

After isolation of the pathogen successfully in OTA media, the pathogen was taken in glass slides to observe the spores under compound microscope in different magnification to get confirmation about the pathogen. Before observing the slide, Lactophenol and cotton blue was added in the slide at 1:1 ratio to stain it and see the spores clearly.

\section{Field data collection and analysis}

From the survey, It was observed that $70 \%$ of the farmers were growing rice crop while $20 \%$ farmers growing vegetables and rest $10 \%$ other crops. From the $70 \%$ farmers growing rice variety, $60 \%$ were cultivating Samba mahsuri (BPT-5204), 25\% pooja variety, 10\% Swarna (MTU 7029) variety and rest 5 $\%$ other varieties which was clearly mention in the below pie chart (Fig. 3). The disease was observed in most of the farmers field after the emergence of panicle. The extent of infection was assessed by calculating the PDI. PDI $=\{$ Sum of all disease rating / (Total no of rating $\times$ Maximum disease grade) $\} \times 100$ (Chiang et al. 2017). The percentage of disease incidence (PDI) was calculated for different varieties.

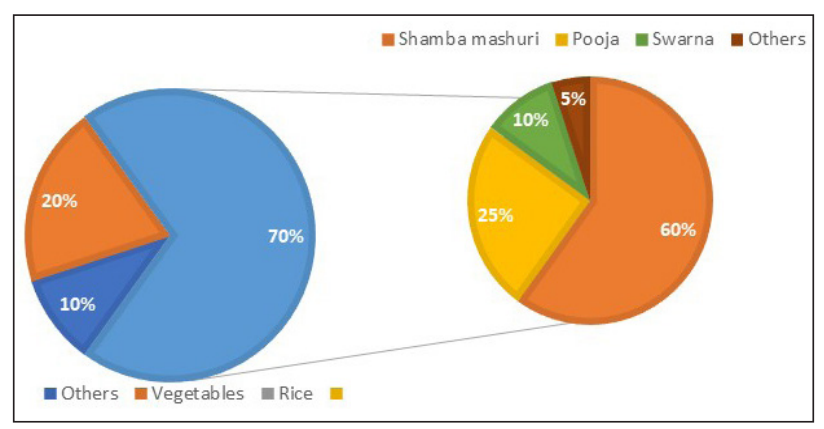

Fig. 3: Percentage of farmers growing different crops and Different varieties of Rice

\section{Meteorological data analysis}

The meteorological data of last 3 years were collected from Indian Meteorological department, Bhubaneswar. The different factors considered are Temperature maximum $\left(\mathrm{T}_{\max }\right)$, Temperature Minimum ( $\left.\mathrm{T}_{\min }\right)$, Relative humidity Maximum ( $\mathrm{RH}$ $\left.{ }_{\max }\right)$ and minimum $\left(\mathrm{RH}_{\min }\right)$, rainfall $(\mathrm{RF})$.

\section{Selection of commercial fungicides and detection of its efficacy}

One of the most important methods to control blast disease is to use efficient fungicides (Manandhar 1984; Sah and Karki 1988; Chaudhary 1999). Therefore, the information of use of different management strategy against this disease was collected from the farmers. The different noted fungicides used against blast disease by the farmers were listed in the below mentioned table (Table 2).

Table 2: Status of five different market based fungicides selected for efficacy detection against Rice blast

\begin{tabular}{|c|c|c|c|c|c|}
\hline $\begin{array}{l}\text { Sl. } \\
\text { No. }\end{array}$ & Trade name & Chemical name & Name of the company & Price & $\begin{array}{l}\text { Recommended } \\
\text { dose }\end{array}$ \\
\hline 1 & BAAN & Tricyclazole $75 \% \mathrm{WP}$ & Indofil & 250 ₹/ 120gm & $300-400 \mathrm{gm} /$ Acre \\
\hline 2 & Fujione & Isoprothiolane $40 \% \mathrm{EC}$ & Rallis India Ltd & 870 ₹/ 11t & $300 \mathrm{ml} / \mathrm{Lt}$ \\
\hline 3 & SAAF & Carbendazim 25\% + Mancozeb 50\% & United Phosphorus Ltd & 369 ₹/500gm & $3-5 \mathrm{gm} / \mathrm{Lt}$ of water \\
\hline 4 & TATA Contaf & Hexaconazole 5\% EC & Rallis India Ltd & $275 ₹ / 500 \mathrm{ml}$ & $250 \mathrm{ml} /$ acre \\
\hline 5 & Sectin & Fenamidone $10 \%$ and Mancozeb 50\% W/W W.G & Bayer crop science Ltd. & $2690 ₹ / 1 \mathrm{~kg}$ & $50 \mathrm{gm} / \mathrm{Ha}$ \\
\hline
\end{tabular}


Among the table 2 mentioned three cultivar varieties, the most tolerant and susceptible rice variety was detected by correlating and analyzing the field data and weather data from 2015-16 to 2017-18.

\section{Software and statistical analysis}

Different statistical analysis was done to correlate the disease severity with the weather condition to know specifically how the blast disease is well dependent upon the climatic variables. For this analysis, different statistical tools were used like Miniab 17, IBM SPSS V.19 etc

\section{RESULTS AND DISCUSSION}

\section{Isolation and characterization of the pathogen}

Cultural isolate of the pathogen was maintained in BOD under $28-30{ }^{\circ} \mathrm{C}$ for $48-72 \mathrm{hr}$. Variation of colony colour ranged from white, light gray, dark brown, black. Smooth to serrated texture, smooth edges at the periphery, sometimes metabolites found. Microscopical observation stated that shape of the conidia as typically pyriform with rounded base, apex narrowed, 2-3 septate/2-4 celled. The colour of the conidia ranged between pale olive to brownish to hyaline. Some of them were very long and narrow, while some were much broader with 2 septa. Conidial size ranged between $25-30 \mu \mathrm{m}(1) \times$ 4-8 $\mu \mathrm{m}$ (b). Conidia are produced from sympodial manner from conidiogenus proliferating cells. The pathogen can sporulate from the host surface and form a scattered surface. Sometimes the aerial mycelia will present, it appears to be branched and hyaline to olivaceous. The newly raising conidiophores are simple to rarely branched that are moderately long and septate. Conidiophores are brownish in colour, denticles are sometimes found on the terminal position (Fig. 4).

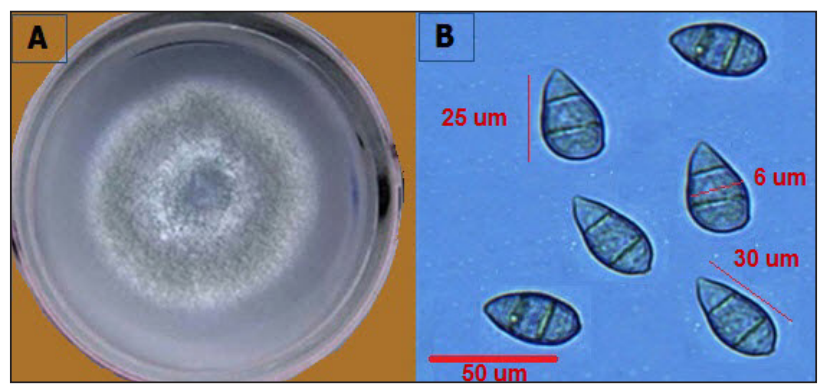

Fig. 4: (A) Culture of Magnaporthe grisea (B) Condia of Magnaporthe grisea (40X)

\section{Comparison of yearly disease severity}

Disease severity data in the form of percent disease index (PDI) were comparatively analyzed between 2015-16 to 2017-18. Outcome of this analysis revealed that blast disease severity was higher $(19.7 \%)$ in $2017-18$ compared to $2015-16(17.6 \%)$ and $2016-17(18.3 \%)$, as well as time series analysis of the disease data showed highest disease severity percentage in October-November, followed by September, December, August and July (Fig. 5). The highest peak disease infestation in the form of PDI is found in October. Results of the time series analysis was shown under the Table 3.

\section{Analysis of weather variables}

Different weather variables (Table 4), which we consider under this study, among which maximum temperature $\left(\mathrm{T}_{\max }\right)$, maximum relative humidity (RH1) and rainfall (RF) play a major role under disease development. This three weather parameters makes a tri-directional pull as a critical interlinked predisposing factor for the disease progress. High temperature range between $30-35{ }^{\circ} \mathrm{C}$ with high humidity (70-90\%) addedly scattered rainfall $(120-180 \mathrm{~mm})$ turns the pathogenic nature more

Table 3: Construction of heat map based on percent disease index from 2015-16 and 2017-18

\begin{tabular}{|c|c|c|c|c|c|c|c|}
\hline \multirow{3}{*}{ Year } & \multicolumn{6}{|c|}{ Disease severity in average Percent Disease Index (PDI) } & \multirow{3}{*}{ Mean } \\
\hline & \multicolumn{6}{|c|}{ Month } & \\
\hline & July & August & September & October & November & December & \\
\hline 2015-2016 & $1.2(9.2)$ & $4.4(12.8)$ & $6.4(14.3)$ & $21.2(26.1)$ & $24.5(28.3)$ & $8(15.4)$ & $10.9(17.6)^{c}$ \\
\hline 2016-2017 & $0.2(7.5)$ & $5.5(14.0)$ & $12.2(19.7)$ & $23.1(27.4)$ & $18.4(24.2)$ & $9.2(17.1)$ & $11.4(18.3)^{b}$ \\
\hline 2017-2018 & $1.5(9.6)$ & $6.3(14.7)$ & $13.8(21.2)$ & $25.3(28.5)$ & $20.2(25.5)$ & $10.9(18.7)$ & $13.0(19.7)^{\mathrm{a}}$ \\
\hline PDI/month & $0.96(8.76)^{f}$ & $5.4(13.83)^{\mathrm{e}}$ & $10.8(18.4)^{c}$ & $23.2(27.33)^{\mathrm{a}}$ & $21.0(26.0)^{b}$ & $9.36(17.0)^{\mathrm{d}}$ & - \\
\hline \multicolumn{2}{|c|}{ * Colour notations } & \multicolumn{2}{|c|}{ Highest value } & \multicolumn{2}{|c|}{ Median value } & Lowest v & \\
\hline
\end{tabular}


favourable. Based on crucial geographical position other weather variables have not so much effect on disease development.

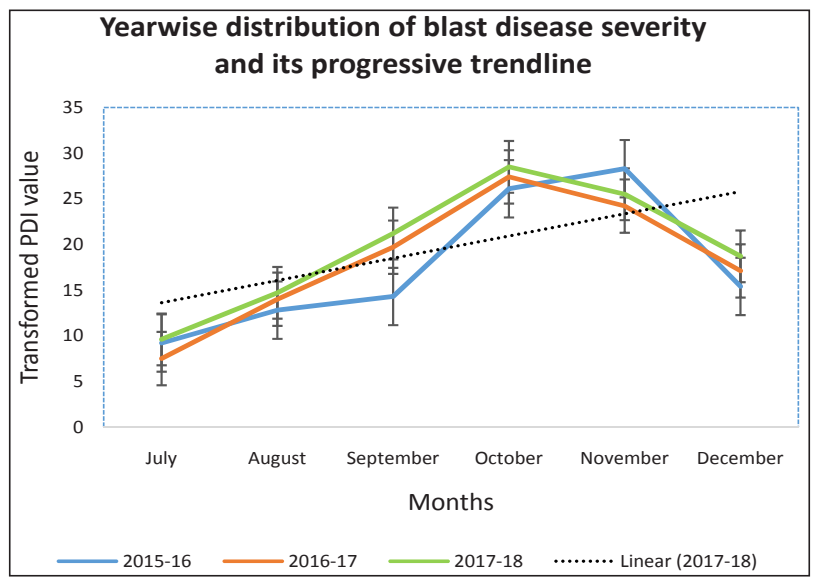

Fig. 5: Trend of Blast disease severity in July to December from 2016-17 to 2017-18 through time series analysis

\section{Correlation of disease data with weather variables}

Different weather variables were correlated with blast disease severity (PDI) (simple correlation with PDI and cross correlation with different factors) from 2015-2018 and found to be significant at 0.01 and 0.05 level. Statistical analysis were performed under Minitab version 17. Weather variables and PDI value were correlated and largest possible variance were measured under orthogonal transformation procedure or by analyzing principal component analysis. Yearly disease prediction from 2015-16 to 2017-18 was analyzed with interaction between weather variables with PDI through multiple regression equation (Fitted line equation) and depicted under table 5. Average increase of meteorological factor compared under table no 6 and its residual vs fitted graph of each variable shown under the picture 6 to 10 .

Correlation: PDI with weather variables $\left(\mathrm{T}_{\max }\right.$ $\mathrm{T}_{\text {min }^{\prime}}$ RH1, RH2, RF) (2015-16)

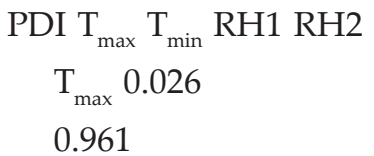

$$
\begin{gathered}
\mathrm{T}_{\text {min }}-0.4860 .843 \\
0.3280 .035
\end{gathered}
$$

$$
\begin{gathered}
\text { RH1 }-0.8530 .4310 .837 \\
0.0310 .3940 .038
\end{gathered}
$$

RH2 -0.744 0.5680 .9190 .973

0.0900 .2390 .0100 .001

RF -0.7130 .6530 .9120 .9270 .924$

\begin{tabular}{|c|c|c|c|c|c|c|c|}
\hline Year & $\begin{array}{l}\text { Weather } \\
\text { variables }\end{array}$ & Jul. & Aug. & Sept. & Oct. & Nov. & Dec. \\
\hline \multirow{6}{*}{ 2015-16 } & Max. Temp $\left({ }^{\circ} \mathrm{C}\right)$ & 32.90645 & 34.23226 & 34.02333 & 33.6129 & 32.24667 & 26.70968 \\
\hline & Min. Temp $\left({ }^{\circ} \mathrm{C}\right)$ & 27.26129 & 26.83871 & 25.83 & 22.50323 & 15.92 & 12.03871 \\
\hline & RH 1 (Morning) & 95.80645 & 94.70968 & 94.53333 & 87.6129 & 79.7 & 86.25806 \\
\hline & RH 2 (Evening) & 83.25806 & 77.22581 & 77.43333 & 68.45161 & 50.4 & 57.64516 \\
\hline & Rainfall (mm) & 278.1 & 281.4 & 330.5 & 81.9 & 0 & 0 \\
\hline & PDI & 9.2 & 12.8 & 14.3 & 26.1 & 28.3 & 15.4 \\
\hline \multirow{6}{*}{ 2016-17 } & Max. Temp $\left({ }^{\circ} \mathrm{C}\right)$ & 32.65161 & 33.37419 & 33.95 & 33.43871 & 31.33333 & 26.41094 \\
\hline & Min. Temp $\left({ }^{\circ} \mathrm{C}\right)$ & 25.9129 & 26.83871 & 26.10667 & 23.73871 & 18.82667 & 15.14719 \\
\hline & RH 1 (Morning) & 97.83871 & 94.77419 & 96 & 94.16129 & 93.33333 & 93.09063 \\
\hline & RH 2 (Evening) & 86.06452 & 76.77419 & 70.96667 & 62.45161 & 53.26667 & 56.4375 \\
\hline & Rainfall (mm) & 464.3 & 193.6 & 227.3 & 41.6 & 0 & 6.6 \\
\hline & PDI & 7.5 & 14 & 19.7 & 27.4 & 24.2 & 17.1 \\
\hline \multirow[t]{6}{*}{$2017-18$} & Max. Temp $\left({ }^{\circ} \mathrm{C}\right)$ & 31.90323 & 31.91935 & 33.16333 & 32.99355 & 29.74333 & 26.45484 \\
\hline & Min. Temp $\left({ }^{\circ} \mathrm{C}\right)$ & 26.2129 & 26.06774 & 26.28667 & 23.87419 & 17.65 & 13.20323 \\
\hline & RH 1 (Morning) & 96.96774 & 96.90323 & 96.26667 & 96.03226 & 93.43333 & 93.8 \\
\hline & RH 2 (Evening) & 86.67742 & 84.70968 & 78.5 & 68.51613 & 58.7 & 59.06452 \\
\hline & Rainfall (mm) & 370 & 448.4 & 200.7 & 101.4 & 16.6 & 0 \\
\hline & PDI & 9.6 & 14.7 & 21.2 & 28.5 & 25.5 & 18.7 \\
\hline
\end{tabular}

0.1120 .1600 .0110 .0080 .009

Table 4: Weather variables from 2015-16 to 2017-18 and their consecutive rice blast disease severity (PDI) per month basis 
Correlation: PDI with weather variables $\left(\mathrm{T}_{\text {max }^{\prime}}\right.$ $\left.\mathrm{T}_{\text {min' }}, \mathrm{RH} 1, \mathrm{RH} 2, \mathrm{RF}\right)$ (2016-17)

PDI $\mathrm{T}_{\max } \mathrm{T}_{\text {min }}$ RH1 RH2

$$
\begin{array}{r}
\mathrm{T}_{\max } 0.056 \\
0.916
\end{array}
$$

$\mathrm{T}_{\min }-0.3070 .910$

$$
0.5540 .012
$$

RH1 -0.676 0.5510 .744

$$
0.1400 .2570 .090
$$

RH2 -0.7810.540 0.8160 .913

0.0660 .2690 .0480 .011

RF -0.805 0.4600 .7060 .9790 .952

$$
0.0530 .3580 .1170 .0010 .003
$$

Correlation: PDI with weather variables $\left(\mathrm{T}_{\max ^{\prime}}\right.$ $\mathrm{T}_{\text {min }^{\prime}}$ RH1, RH2, RF) (2017-18)

$$
\begin{gathered}
\mathrm{T}_{\max } 0.049 \\
0.927 \\
\mathrm{~T}_{\text {min }}-0.2940 .937 \\
0.5710 .006
\end{gathered}
$$$$
\text { PDI } \mathrm{T}_{\max } \mathrm{T}_{\min } \text { RH1 RH2 }
$$

RH1 -0.486 0.7880 .932

\begin{tabular}{|c|c|c|c|c|c|c|}
\hline Eigenvalue & le 4.6909 & 1.1829 & 0.0937 & 0.0269 & 0.0055 & -0.0000 \\
\hline Proportion & 0.782 & 0.197 & 0.016 & 0.004 & 0.001 & -0.000 \\
\hline Cumulativ & ve 0.782 & 0.979 & 0.995 & 0.999 & 1.000 & 1.000 \\
\hline Variable & PC1 & PC2 & PC3 & PC4 & PC5 & PC6 \\
\hline PDI & -0.337 & 0.617 & 0.307 & 0.607 & 0.075 & 0.194 \\
\hline $\mathrm{T}_{\max }$ & 0.299 & 0.697 & -0.218 & -0.239 & -0.272 & -0.496 \\
\hline $\mathrm{T}_{\mathrm{m}}$ & 0.438 & 0.281 & 0.217 & -0.390 & 0.044 & 0.727 \\
\hline RH1 & 0.445 & -0.225 & 0.232 & 0.437 & -0.711 & 0.028 \\
\hline RH2 & 0.453 & -0.065 & 0.580 & 0.088 & 0.531 & -0.406 \\
\hline RF & 0.451 & 0.013 & -0.649 & 0.472 & 0.362 & 0.149 \\
\hline
\end{tabular}

$$
0.3280 .0630 .007
$$

RH2 -0.688 0.6780 .8910 .947

$$
0.1310 .1390 .0170 .004
$$

\begin{tabular}{|c|c|c|c|c|c|c|c|}
\hline Eigenvalı & 4.46 & 351 & 3327 & 0.1705 & 0.0283 & 0.0050 & 0.0000 \\
\hline Proportio & n $\quad 0.74$ & & .222 & 0.028 & 0.005 & 0.001 & 0.000 \\
\hline Cumulati & ve 0.74 & & 966 & 0.994 & 0.999 & 1.000 & 1.000 \\
\hline Variable & PC1 & PC2 & & C3 & PC4 & PC5 & PC6 \\
\hline PDI & -0.330 & -0.59 & 6 & 428 & 0.500 & -0.220 & 0.230 \\
\hline $\mathrm{T}_{\max }$ & 0.307 & -0.65 & & 0.018 & -0.599 & -0.290 & -0.192 \\
\hline $\mathrm{T}_{\min }$ & 0.410 & -0.40 & $6-$ & 0.399 & 0.303 & 0.612 & 0.204 \\
\hline RH1 & 0.453 & 0.074 & & .671 & 0.158 & 0.269 & -0.492 \\
\hline RH2 & 0.464 & 0.103 & & 0.312 & 0.496 & -0.634 & -0.169 \\
\hline RF & 0.457 & 0.193 & & .332 & -0.168 & -0.136 & 0.773 \\
\hline
\end{tabular}

RF -0.725 0.5590 .8010 .8760 .957

$$
0.1030 .2490 .0550 .0220 .003
$$

\section{Principal Component Analysis: PDI, $\mathrm{T}_{\text {max }^{\prime}} \mathrm{T}_{\text {min }^{\prime}}$} RH1, RH2, RF (2015-16)

Eigen-analysis of the Correlation Matrix
Principal Component Analysis: PDI, $\mathrm{T}_{\max }, \mathrm{T}_{\min ^{\prime}}$ RH1, RH2, RF (2016-17)

Eigenanalysis of the Correlation Matrix

Principal Component Analysis: PDI, $\mathrm{T}_{\max ^{\prime}}, \mathrm{T}_{\text {min }^{\prime}}$ RH1, RH2, RF (2017-18)

Eigenanalysis of the Correlation Matrix

\begin{tabular}{llllllll}
\hline Eigenvalue & 4.6277 & 1.2372 & 0.0708 & 0.0609 & 0.0033 & -0.0000 \\
Proportion & 0.771 & 0.206 & 0.012 & 0.010 & 0.001 & -0.000 \\
Cumulative & 0.771 & 0.977 & 0.989 & 0.999 & 1.000 & 1.000 \\
\hline \hline Variable & PC1 & PC2 & PC3 & PC4 & PC5 & PC6 \\
\hline PDI & -0.266 & 0.728 & -0.306 & -0.407 & -0.371 & -0.047 \\
$\mathrm{~T}_{\max }$ & 0.361 & 0.559 & 0.020 & 0.391 & 0.450 & -0.449 \\
$\mathrm{~T}_{\min }$ & 0.440 & 0.282 & 0.002 & 0.300 & -0.190 & 0.775 \\
RH1 & 0.452 & 0.069 & 0.479 & -0.720 & 0.201 & 0.045 \\
RH2 & 0.459 & -0.132 & 0.108 & 0.112 & -0.745 & -0.439 \\
$\mathrm{RF}$ & 0.436 & -0.236 & -0.815 & -0.245 & 0.169 & -0.024 \\
\hline
\end{tabular}

Table 5: Multiple Regression equation (Fitted line Equation) for prediction of rice blast disease severity

\begin{tabular}{llll}
\hline Factors & 2015-16 & 2016-17 & 2017-18 \\
\hline $\mathrm{T}_{\text {max }}$ & PDI $=11.96+$ & $\mathrm{PDI}=13.78+$ & $\mathrm{PDI}=15.58+$ \\
& $0.231 \mathrm{~T}_{\text {max }}$ & $0.142 \mathrm{~T}_{\text {max }}$ & $0.133 \mathrm{~T}_{\text {max }}$ \\
$\mathrm{T}_{\text {min }}$ & $\mathrm{PDI}=27.19-$ & $\mathrm{PDI}=28.88-$ & $\mathrm{PDI}=27.93-$ \\
& $0.3786 \mathrm{~T}_{\text {min }}$ & $0.4642 \mathrm{~T}_{\text {min }}$ & $0.3705 \mathrm{~T}_{\text {min }}$ \\
$\mathrm{RH} 1$ & $\mathrm{PDI}=101.7-$ & $\mathrm{PDI}=273.9-$ & $\mathrm{PDI}=226.9-$ \\
& $0.9295 \mathrm{RH} 1$ & $2.694 \mathrm{RH} 1$ & $2.168 \mathrm{RH} 1$ \\
$\mathrm{RH} 2$ & $\mathrm{PDI}=44.85-$ & $\mathrm{PDI}=48.37-$ & $\mathrm{PDI}=47.63-$ \\
& $0.3846 \mathrm{RH} 2$ & $0.4441 \mathrm{RH} 2$ & $0.3843 \mathrm{RH} 2$ \\
$\mathrm{RF}$ & $\mathrm{PDI}=23.56-$ & $\mathrm{PDI}=23.31-$ & $\mathrm{PDI}=24.83-$ \\
& $0.03015 \mathrm{RF}$ & $0.03208 \mathrm{RF}$ & $0.02706 \mathrm{RF}$ \\
\hline
\end{tabular}


Table 6: Yearly average of weather variable correlation with PDI

\begin{tabular}{lllllll}
\hline Year & Max. Temp $\left({ }^{\circ} \mathrm{C}\right)$ & Min. Temp. $\left({ }^{\circ} \mathrm{C}\right)$ & RH 1 (Morning) & RH 2 (Evening) & Rainfall (mm) & PDI \\
\hline $2015-16$ & 32.29 & 21.73 & 89.77 & 69.07 & 161.98 & 17.68 \\
$2016-17$ & 31.86 & 22.76 & 94.87 & 67.66 & 155.57 & 18.32 \\
$2017-18$ & 31.03 & 22.22 & 95.57 & 72.69 & 189.52 & 19.70 \\
\hline
\end{tabular}

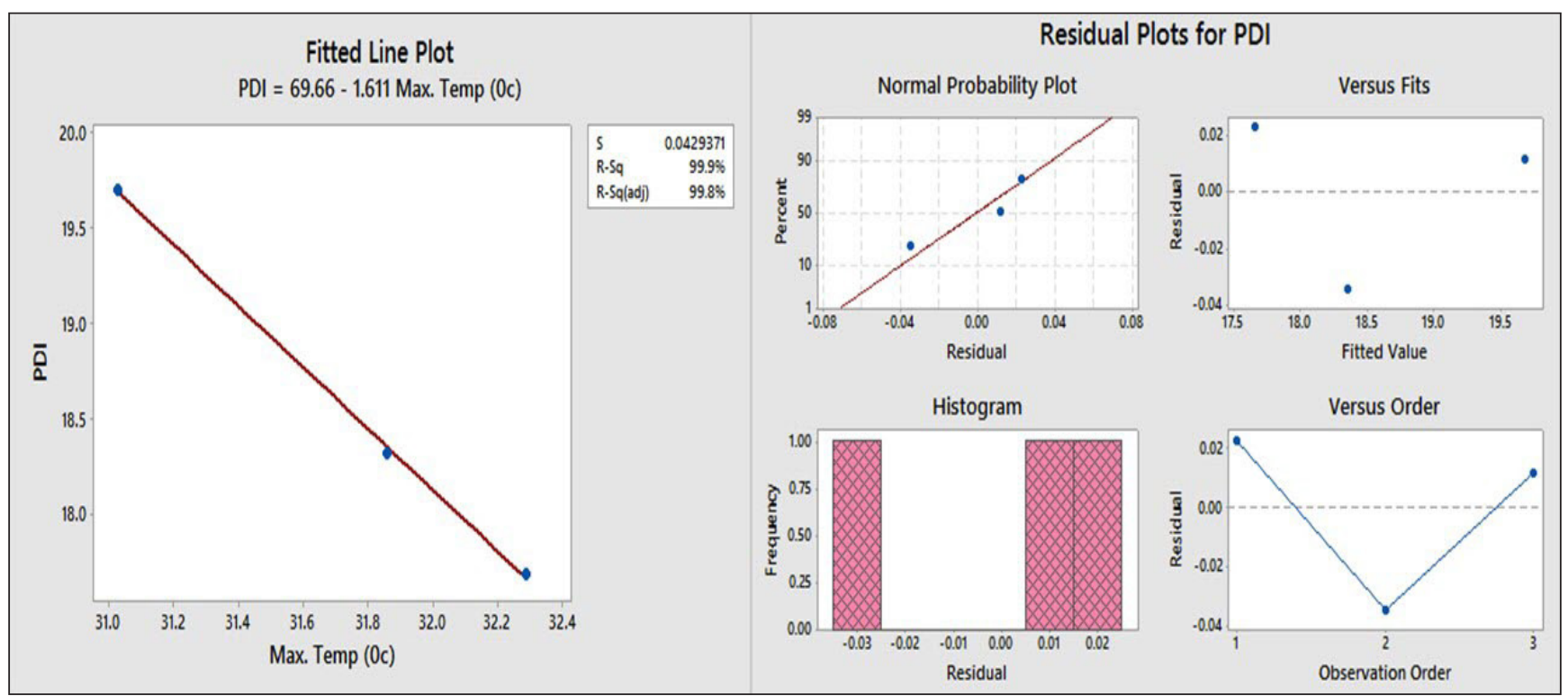

Fig. 6: Correlation with Tmax and PDI under residual vs fitted graph

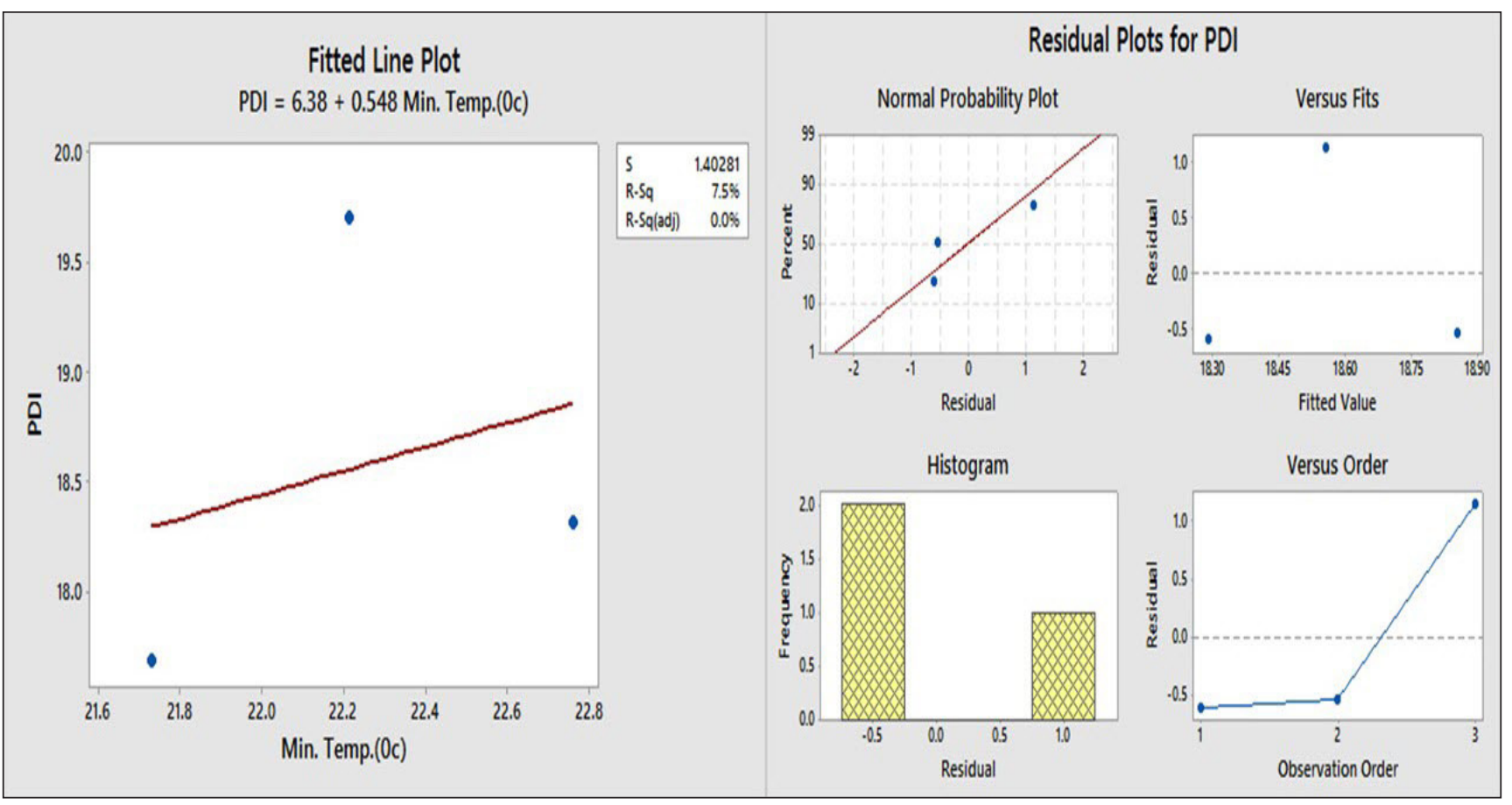

Fig. 7: Correlation with $\mathrm{T}_{\min }$ and PDI under residual vs fitted graph 


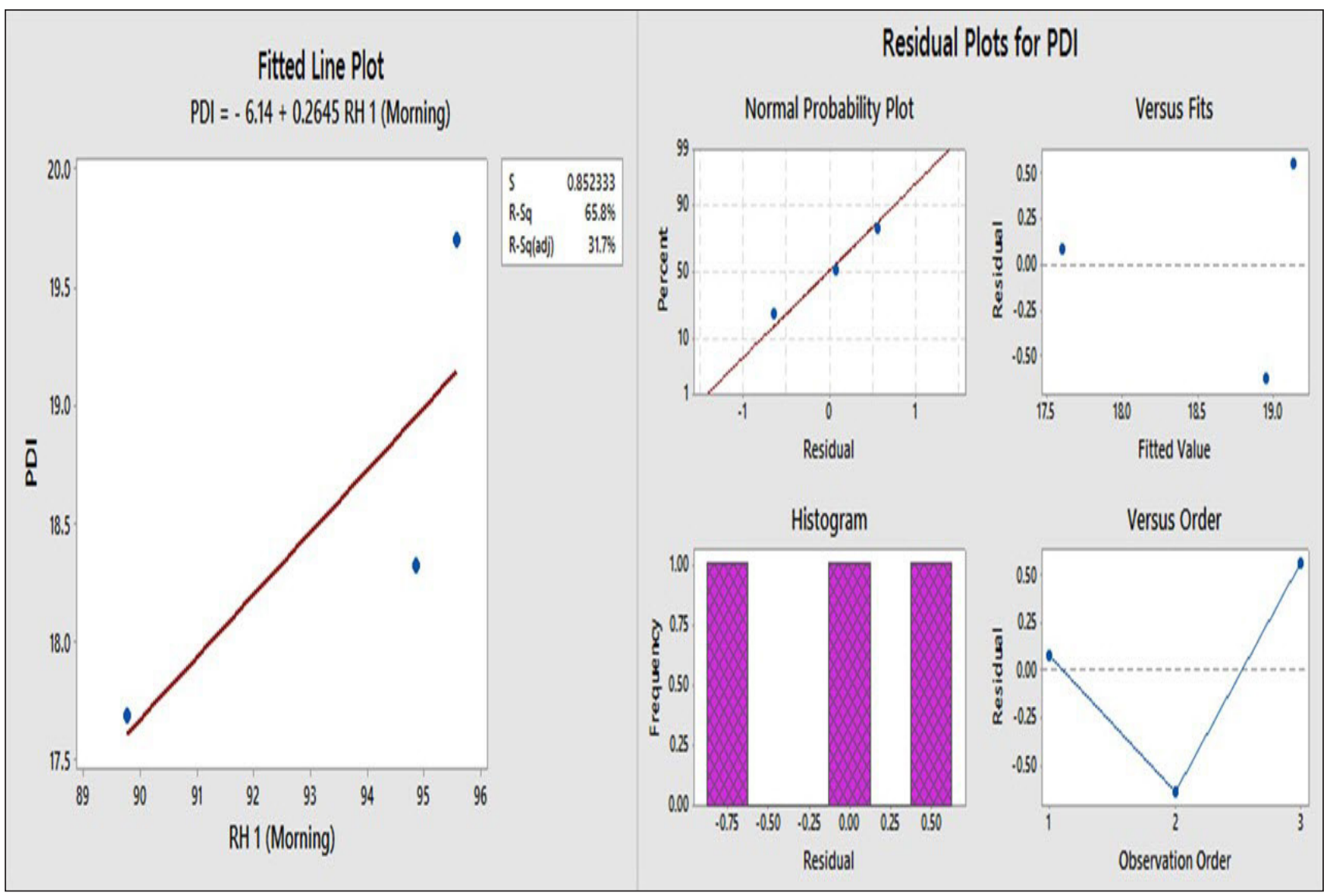

Fig. 8: Correlation with RH1 and PDI under residual vs fitted graph

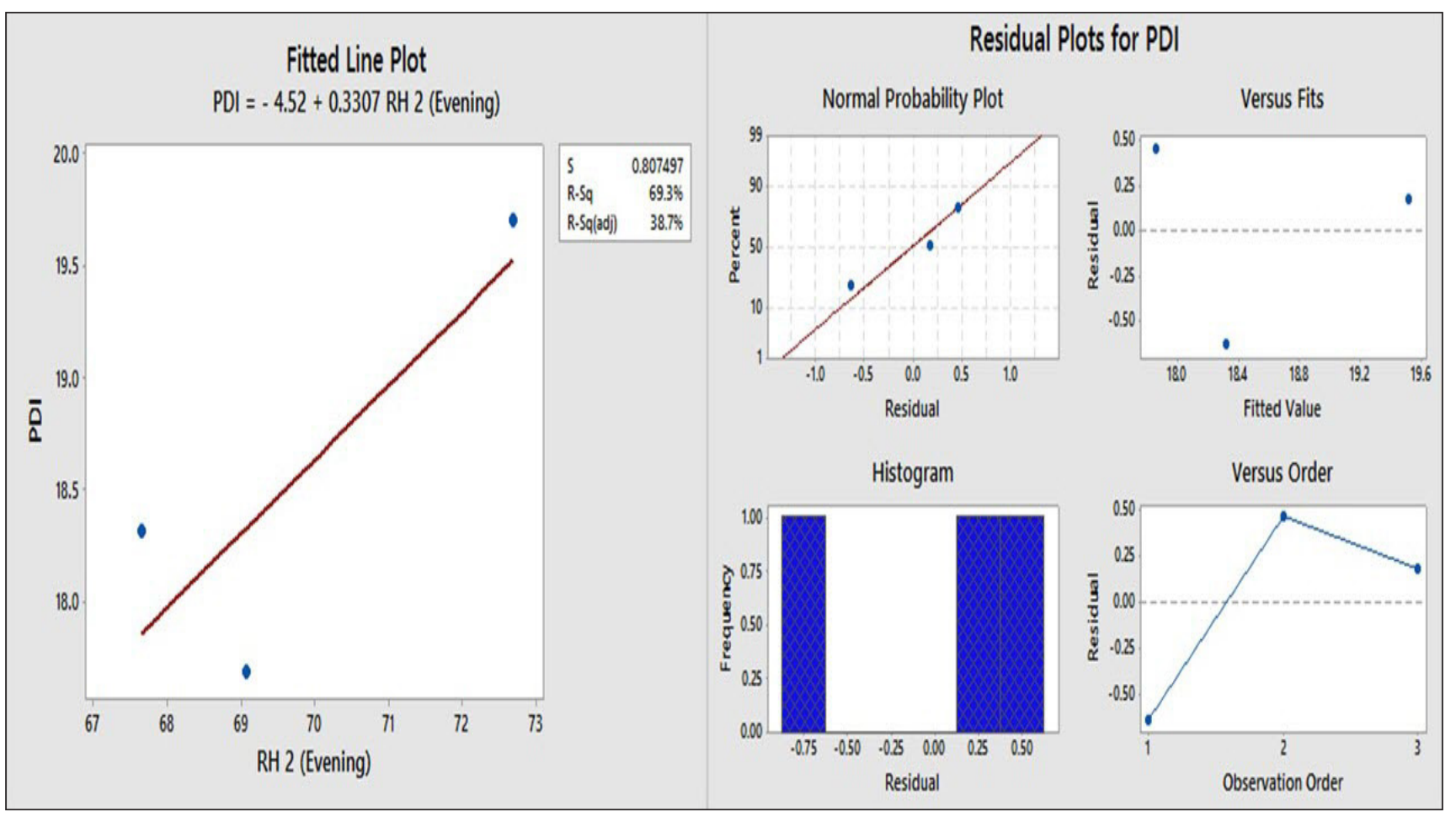

Fig. 9: Correlation with RH2 and PDI under residual vs fitted graph 


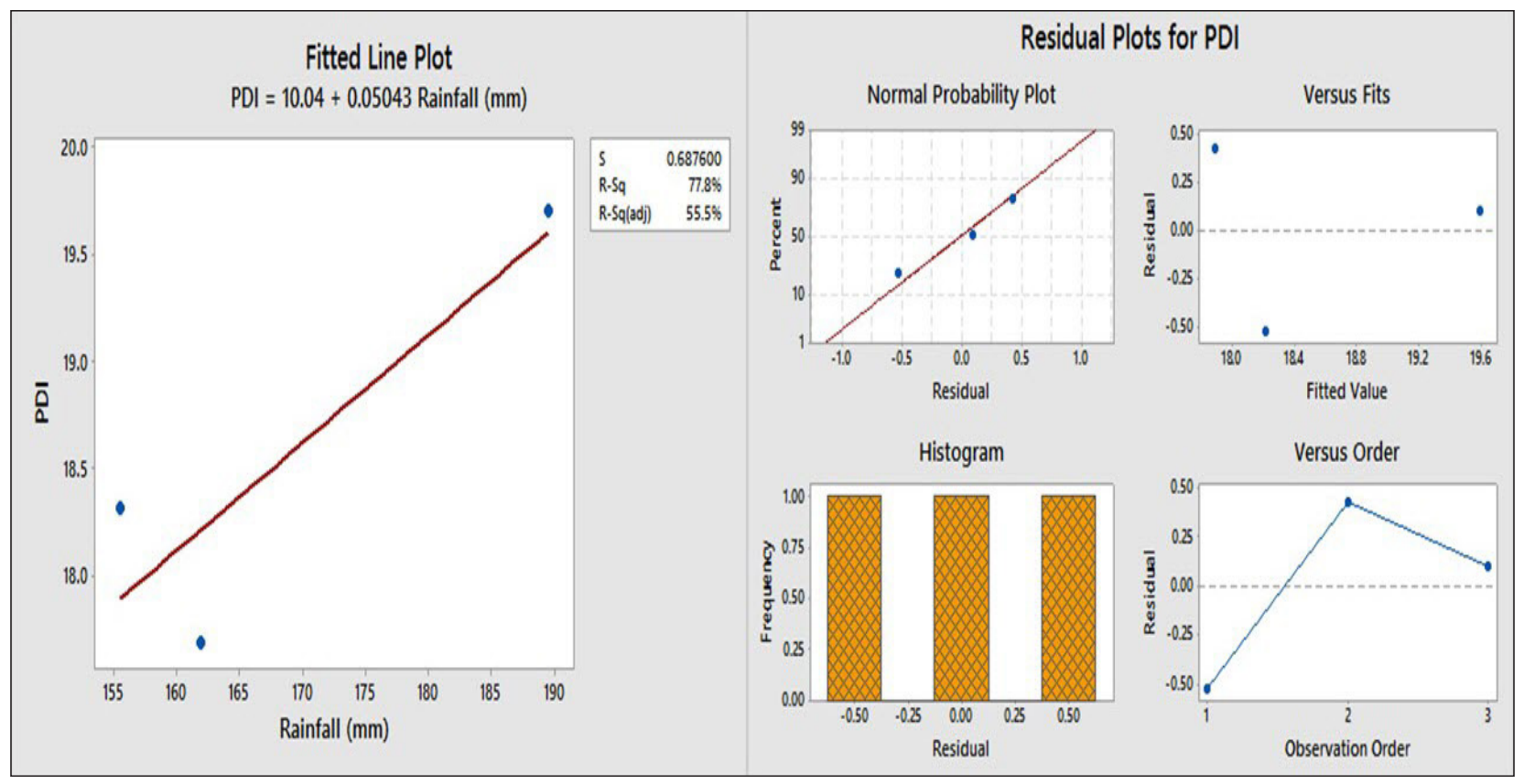

Fig. 10: Correlation with Rainfall and PDI under residual vs fitted graph

Table 7: Efficacy detection of five market based fungicides and their interaction with varietal tolerance

\begin{tabular}{lllllllllll}
\hline & & \multicolumn{3}{c}{ Pooja } & \multicolumn{3}{c}{ Samba mahsuri (BPT-5204) } & \multicolumn{3}{c}{ Swarna (MTU 7029) } \\
\cline { 3 - 10 } $\begin{array}{l}\text { S1. } \\
\text { No }\end{array}$ & Fungicide & $\begin{array}{l}\text { Blast } \\
\text { severity } \\
\text { \% }\end{array}$ & $\begin{array}{l}\text { \% } \\
\text { Disease } \\
\text { control }\end{array}$ & $\begin{array}{l}\text { \% Increase } \\
\text { yield over } \\
\text { control }\end{array}$ & $\begin{array}{l}\text { Blast } \\
\text { severity } \\
\text { \% }\end{array}$ & $\begin{array}{l}\text { \% } \\
\text { Disease } \\
\text { control }\end{array}$ & $\begin{array}{l}\text { \% Increase } \\
\text { yield over } \\
\text { control }\end{array}$ & $\begin{array}{l}\text { Blast } \\
\text { severity } \\
\text { \% }\end{array}$ & $\begin{array}{l}\text { \% } \\
\text { Disease } \\
\text { control }\end{array}$ & $\begin{array}{l}\text { \% Increase } \\
\text { yield over } \\
\text { control }\end{array}$ \\
\hline 1 & BAAN & 1.85 & 89.23 & 65.30 & 1.52 & 87.62 & 62.30 & 0.50 & 98.55 & 52.08 \\
2 & Fujione & 1.72 & 81.32 & 49.31 & 1.90 & 85.76 & 58.95 & 1.09 & 95.28 & 40.22 \\
3 & SAAF & 5.71 & 46.39 & 15.32 & 4.85 & 52.64 & 14.65 & 1.23 & 89.36 & 17.45 \\
4 & TATA Contaf & 1.93 & 73.55 & 24.65 & 2.37 & 68.23 & 32.84 & 1.13 & 91.37 & 35.12 \\
5 & Sectin & 2.29 & 65.75 & 22.38 & 3.89 & 61.58 & 28.54 & 1.18 & 86.49 & 25.40 \\
\hline CV (\%) & 62.59 & & & 48.62 & & & 29.04 & & \\
\hline
\end{tabular}

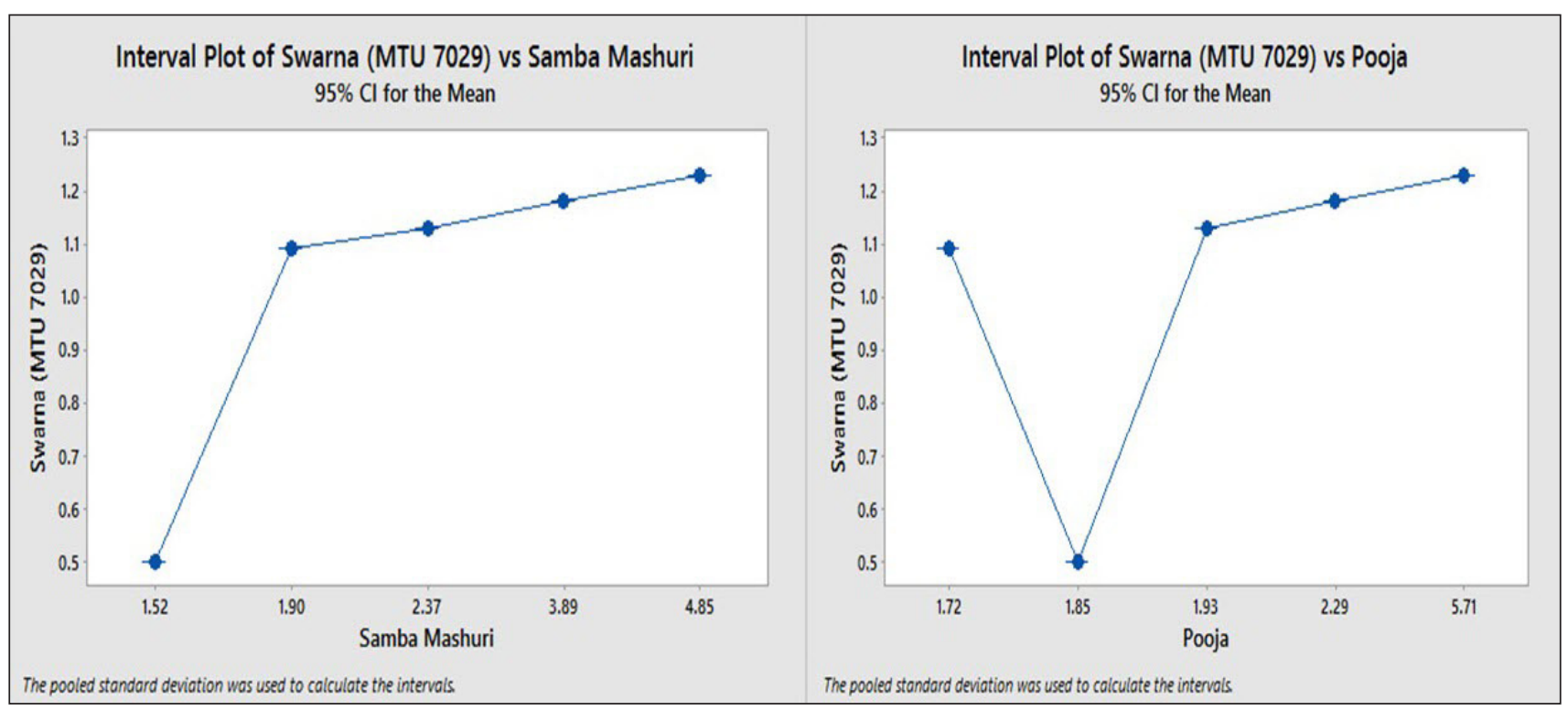

Fig. 11: Comparison of disease tolerance superiority of Swarna than Pooja and Samba Mashuri through interval plot 


\section{Comparison of blast tolerant cultivated rice variety}

Blast tolerant rice variety selection among cultivated varieties depends on nature of susceptibility. Among the three cultivated rice varieties, Pooja and Samba Mahsuri (BPT-5204) are the most susceptible blast varieties $(5.71 \%$ and $4.85 \%)$ compared to Swarna (MTU 7029) with a disease incidence level of $1.23 \%$. Again this three varieties were treated under different types of commercial chemical fungicides and their disease severity, disease control (\%) were depicted under the table 7. Comparison of disease tolerance superiority of Swarna than Pooja and Samba Mashuri were tested and plotted under interval plot (Fig - 11).

\section{Efficiency of fungicide against blast disease}

Different market based fungicides were evaluated to control different types of blast symptoms under field conditions and their ultimate effects on productivity. During the experiment leaf blast severity was found to be significantly less by using some specific fungicides, where as in other cases the severity was not downwards or more (without treatment). Among the five selected fungicides, Tricyclazole 75\% WP (trade name - BAAN/ Indofils) and $40 \%$ EC formulation of Isoprothiolane (trade name - Fujione / Rallis India Limited) are the two sequential most effective fungicides compared different market based available fungicides and showed best efficacy against neck, collar and leaf blasts. Results of the experiment shown under the table 7.

Rice blast is one of the most severe disease in South eastern India. Variable epidemiological factors affect greatly on the disease establishment, development and severity resulting in huge crop loss. It was evident from the studies of simple correlation coefficient between weather variables and PDI that maximum temperature, maximum relative humidity and rainfall were positively and significantly correlated with PDI i.e. the increment of rainfall and maximum relative humidity additionally interaction between this two factors and maximum temperature enhanced leaf blast disease by constructing one triangular pool. Nearly 30-35 degree temperature with high moisture (80-90\%) and scattered rainfall (120-150 mm) helps in disease progress. As par
Vishwanath and Channamma (1988) blast pathogen prefers optimum temperature and with high humidity and heavy rainfall for outbreaks. As par Bhatt and Chauhan (1985) observed that minimum temperature, more number of rainy days, higher rainfall are the most crucial factors of which favored blast disease. Patel and Tripathi, 1998 and Pall, 1988 reported nearly $22-29{ }^{\circ} \mathrm{C}$ temperature with 85-99 per cent $\mathrm{RH}$ was act as a triggering factor for the blast. In 1994, Jain et al. reported moderate temperatures $\left(21-29^{\circ} \mathrm{C}\right)$ with more than $80 \%$ mean atmospheric relative humidity during reproductive period favored the disease development, which is in conformity with our recent findings. Prediction equation from 2015-16 to 2017-18 can be used for forecasting leaf blast disease severity and can be used as a component of Integrated Disease Management (IDM) programme by decreasing the use of chemical spray as a control measure and used as a forecasting machinery under RAWEP programme. Therefore, it is concluded from the experimental results that, out of five independent weather variables considered under this research or prediction of PDI, maximum temperature, maximum $\mathrm{RH}$ and maximum $\mathrm{RF}$ were identified as critical weather parameters following principal component analysis. All the independent factors are somehow positively, negatively or partially correlated with disease severity. Effect of different fungicides to control blast disease were tested under this research under positive interaction with three mostly cultivated varieties. Magar et al. in 2015 found Tricycazole $22 \%$ and Hexaconazole $5 \%$ combination is the best effective fungicides against blast disease and got more yield after applying the same. we have observed quite similar result by our research, where Tricyclazole 75\% WP (trade name - BAAN/ Indofils) and $40 \%$ EC formulation of Isoprothiolane (trade name - Fujione / Rallis India Limited) are the two sequential most effective fungicides compared different market based available fungicides and showed best efficacy against neck, collar and leaf blasts with good yield. Environment itself as a laboratory of its own, we are not encouraging to farmers to use chemical measure, as because it is very much harmful for sustainable agriculture but it can useable as an IDM component when the disease is not manageable or very severe stage. 


\section{ACKNOWLEDGEMENTS}

We would like to thank Prof. D.N. Rao (Vice President), Prof. Supriya Pattanayak (Vice Chancellor), Prof. S.P. Nanda (Dean) for giving a platform as a programme supervisor under RAWEP scheme at Centurion University, additionally IMD, Bhubaneswar, Odisha for their meteorological data support.

\section{REFERENCES}

Bhatta, J.C. and Chauhan, V.S. 1985. Epidemiological studies on neck blast of rice in U.P. hills. Indian Phytopath., 38: 126-130.

Chaudhary, B. and Sah, D.N. 1997. Effect of promising rice genotypes on leaf blast disease progression. Nepal Agriculture Research Journal, 1: 27-31.

Chaudhary, B. 1999. Effect of blast disease on rice yield. Nepal Agriculture Research Journal, 3: 8-13.

Chiang, K.S., Liu, H.I. and Bock, C.H. 2017. A discussion on disease severity index values. Part 1: Warning on inherent errors and suggestions to maximise accuracy. Annals of Applied Biology. 171(2): 139-154.

Das, S.R. and Naik, B.S. 2015. Progress of rice research in Odisha (1965-2015). Technical report.

Georgopoulos, S.G. and Ziogas, B.N. 1992. Principles and methods for control of Plant diseases, Athens, pp. 236.

Hembrom, K.C., Nath, R., Mondal, B. and Dutta, S. 2019. Pathogenic variability of Ralstonia solanacearum causing Bacterial wilt of Brinjal in Red and Lateritic Agro-climatic zone of West-Bengal. International journal of Agriculture, Environment and Biotechnology, 12(2): 151-156.

Inglis, D.A., Hagedorn, D.J. and Rand, R.E. 1988. Use of dry inoculums to evaluate beans for resistance to anthracnose and angular leaf spot. Plant Dis., 72: 771-774.

Jain, K., Gupta, J.C., Yadav, H.S. and Tikle, A.N. 1994. Assesment of stable resistance to blast in finger millet. Adv. Plant Sci., 7(2): 330-334.

Kariaga, M.G., Wakhungu, J. and Were, H.K. 2016. Identification of Rice Blast (Pyricularia oryzae cav.) Races from Kenyan Rice growing regions using culture and classical characterization. Journal of Research in Agriculture and Animal Science, 4(4): 16-24.

Li-wang, F., Wen-bo, L., Xiao-zhou, X., Feng-cheng, Y., Liwei, Z., Jin-tao, L., Yuan-jun, B., Zhen-yu, L., Wen-sheng, Z., Jun, Y. and You-liang, P. 2019. A rapid approach for isolating a single fungal spore from rice blast diseased leaves. Journal of Integrative Agriculture, 18(6): 1415-1418.

Magar, P.B., Acharya, B. and Pandey, B. 2015. Use of chemical fungicides for the management of rice blast (Pyricularia grisea) disease at Jyotinagar, Chitwan, Nepal. International journal of Applied Sciences and Biotechnology, 3(3): 474-478.
Manandhar, H.K. 1984. Seed treatment against rice leaf blast. Nepalese Journal of Agriculture, 15: 189.

Manandhar, H.K., Thapa, B.J. and Amatya, P. 1985. Efficacy of various fungicides on the control of rice blast disease. Journal of Institute of Agriculture and Animal Sciences (Nepal). 6: 21-29.

Mariappan, V., Rajeswari, E. and Kamalakannan, A. 1995. Management of Rice blast, Pyricularia oryzae by using neem (Azadirachta indica) and other plant products. In: Mariappan, V.[Ed.] Neem for the Management of crop Diseases. Associated Publishing C0., New Delhi, India, pp. 3-10.

Mbodi, Y., Gaye, S. and Diwa, S. 1987. The role of tricyclazole in rice protection against blast and cultivar improvement. Parasitica, 43: 187-198.

Moletti, M., Giudici, M.L., Nipoti, E. and Villa, B. 1988. Chemical control trials against rice blast in Italy. Informatore Fitopatologic, 38: 41-47.

Naidu, V.D. and Reddy, G.V. 1989. Control of Blast (BI) in main field and nursery with some new fungicides. R.P.P., 69: 209.

Patel, R.P. and Tripathi, S.K. 1998. Epidemiology of blast of finger millet caused by Pyricularia grisea (Cke) Sacc. Adv. Plant Sci., 11: 73-75.

Pradhan, J., Baliarsingh, A., Biswal, G., Das, M.P. and Pasupalak, S. 2018. Effect of weather parameters on Infestation of Blast Disease (Pyricularia oryzae) in Rabi season (Oryzae sativa L.) in East \& South Eastern Coastal Plain of Odisha. International journal of Current Microbiology and Applied Science, 7(11): 893-900.

Ou, S.H. 1980. A look at worldwide Rice blast disease control. Plant Disease, 64: 439-445.

Sah, D.N. and Karki, P.B. 1998. Efficacy of seed treatment and crop management in controlling leaf blast disease of rice. Paper presented in The rice Technical working group Meeting held at Pareanipur, Nepal from 6-8 March, 1988.

Sesma, A. and Osbourn, A.E. 2004. The Rice leaf blast pathogen undergoes developmental processes typical of root-infecting fungi. Nature, 431: 582-586.

Talbot, N.J. 2003. On the trail of a cereal killer: Exploring the biology of Magnaporthe grisea. Annual Reviews in Microbiology, 57: 177-202.

Viswanath, S. and Channamma, L. 1988. Survey and Surveillance of Rabi disease and the management in Karnataka. In: National seminar on pest Surveillance for Integrated pest Management. Tamilnadu Agricultural University, Coimbatore, pp. 35.

Zeigler, R.S. and Correa, F.J. 2000. Applying Magnaporthe grisea population analyses for durable rice blast resistance. APSnet Features. Online. Doi:10.1094/APSnetFeature- 